\title{
The Etymological Path to Moral Meaning: Adam and the Names
}

\author{
Ghassan el Masri \\ Bavarian Research-Center for Interreligious Discourses, \\ Friedrich-Alexander-Universität Erlangen-Nürnberg, Erlangen, Germany \\ ghassan.masri@fau.de
}

\begin{abstract}
This paper advances the claim that an investigation into the significance of Qurānic terms must consider the semantic etymology of the elements under investigation, especially terms that have developed into technical concepts in Islamic theology and philosophy like the ethical variety investigated in this volume. The present article will give some of the salient reason for this imperative and demonstrate the value of semantic etymology in understanding the anthropological dimensions of theological concepts. Semantic etymology, the practice of uncovering the 'original' imposition of a word-thing relation ( $a s ̣ l$ al-wad ${ }^{\prime}$ ) by deducing the meaning of a word from the meaning of other words sharing the same lexeme was more than a descriptive linguistic science in the Arab-Islamic tradition. In late antiquity the Greek and Latin science of etymologia, like the Arabic ishtiqāq al-ma'ná (later 'ilm al-wad '), was a fully-fledged instrument of conceptual analysis for the reader and a powerful tool of discursive authority for both author and reader. Semantic etymology offers an account, not only of the original word-thing relation, but also the essential nature of the object. In our current moment in the history of philosophy where 'essences' and 'essential qualities' have lost almost all currency, the article opens the door for a reconsideration of the worth of 'etymologies' as sound and useful anthropological and philosophical objects of analysis.
\end{abstract}

\section{Keywords}

Qurān - essence - origin of language - etymology - lexicography - al-Rāghib al-Iṣfahānī - 'ilm al-ishtiqāq - zakāt 


\section{المنهاج التأثيل وتأصيل المعنى الأخلاقي: آدم والأسماء}

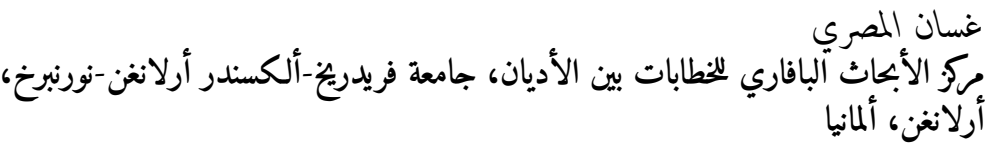

\section{انلإمة}

"يجثث هذا المقال الججج المنطقية والكلامية التي تبين أهمية دلالة جذر الكلمة في تحليل المصطلح القرآني

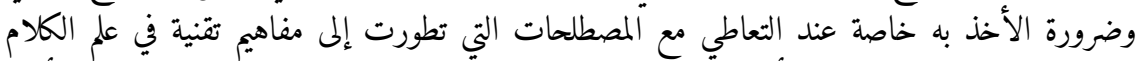

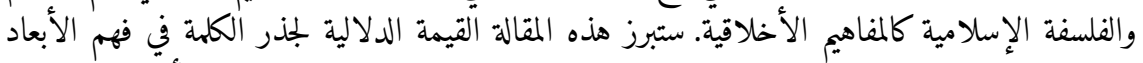

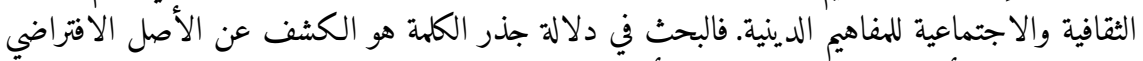

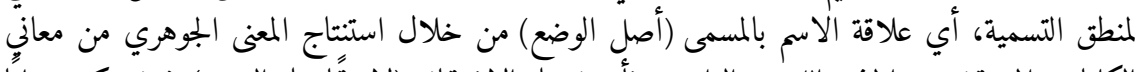

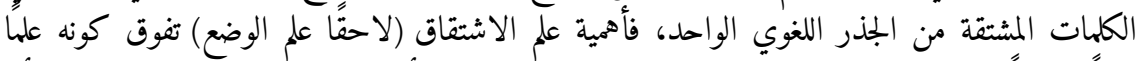

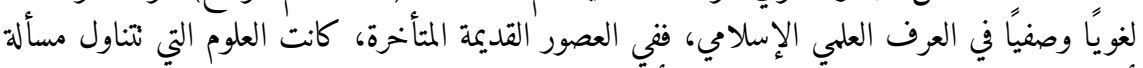

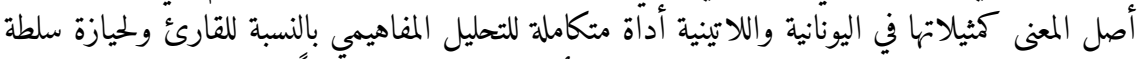

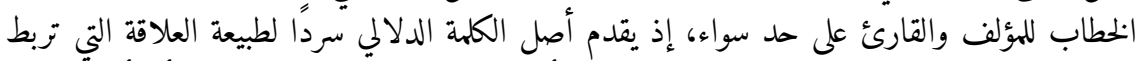

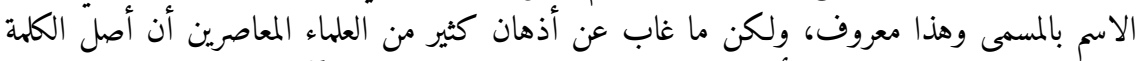

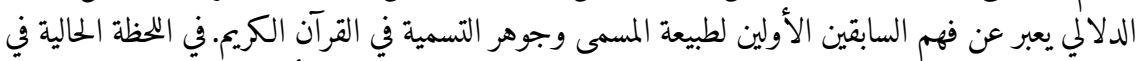

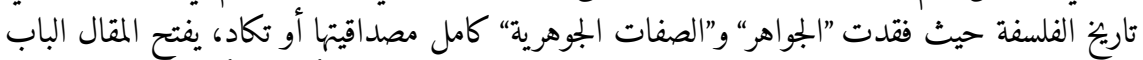

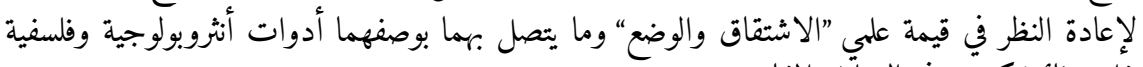
ذات فائدة كبرى في التحليّل المفاهيمي.

\section{الكلمات المفتاحية}

القرآن - الجوهر - أصل اللغة - أصل المعنى - علم المعاجم - الراغب الأصفهاني - علم الاشتقاق -

Any modern discussion of the theological significance of Qurānic concepts must involve a discussion of etymologies, and this, in turn, requires a distinction. The term 'etymology' has become ambivalent in the modern era and designates two very different modes of enquiry: one historic and another semantic (Chantraine 1970, 80-95). Although both are enquiries into the origins of words, 'historical etymology', the sort found in modern philological enquiries and modern lexical sources, consists of the practice of tracing the historical 
origin of the word to another, typically older language, that belongs to the same family of languages (the Semitic languages in the case of Arabic). Its counterpart, 'Semantic etymology', variants of which one encounters in all sorts of pre-modern literature, and was formally discussed as early as in Plato's dialogues (Cratylus), designates a different procedure of etiological enquiry and consists of the practice of exploring the logical origin of the word by giving an account of why the object (material or abstract) is referred to by that word (or name) and not another. As such, semantic etymology explores the original word-thing relation and informs us, therefore, not only of the meaning of the word, but of the 'focal meaning's of the lexeme and the essence of the object so-called. The semantic strand of etymology is equivalent to the old science of etymologia that we know was practiced up until the early modern period and was ubiquitous in late antiquity (Amsler 1989; Bloch 1983; el Masri 2020) before it was eclipsed by the philological science of 'historical etymology'. In modern Islamic and Qurānic studies, the [semantic] etymological accounts that were handed over by the Islamic tradition were considered mistaken from the perspective of historical philology and were dismissed as 'inventions' of Muslim scholars or as 'folk' or 'popular' etymologies, by modern philologists that disregarded or misunderstood the very function of the old practice. Semantic etymologies, they mistakenly thought, misconstrued the 'true' origins of the word that only empirical historical enquiry can uncover. In fact, it was modern scholars, in a historical moment of positivist blindness-or hubris- that misconstrued the purpose of semantic etymologies (Zaborski 2004, 143-8; Larcher 1995; Barr, 1961). A clarification and a distinction are therefore necessary.

That semantic etymologies, like historic etymologies, are both etiological accounts, might have confused some into thinking that the two have comparable or even matching intellectual aims, which they don't. Ilm al-ishtiqā $q$ (and later 'ilm al-wad') consistently explored two things that are effectively related: it investigated the logical connection between different terms that share the same phonetic skeleton (lexeme) on the one hand, and gave an account of the relation between the 'term' and its 'referent' on the other. Muslim scholars practicing etymologia like their Greek and Latin predecessors neither claimed nor sought to provide the historical origin of the term, even when they knew that the term derived from Hebrew, Syriac or Persian. In fact, when a Muslim

1 The idea that all things named by the same thing, share the same quality, or that terms have a 'focal meaning' is provided at the Nicomachean Ethics (Aristotle 2000, 1096 b 23-9), in Aristotle's comments on the good, he writes: "but in what sense are different things called good? Is it because they are all derivative of a single thing or [i.e. equivalently] because they are all directed towards a single thing?" 
scholar or lexicographer provides an account of the aṣl or the 'origin of the name' what they are in fact engaged in-from our modern perspective-is a form of conceptual analysis that seeks to relate the nature of the object to our ability to name it and thus identify its essential qualities. In other words, establishing the word-thing relation that traditional scholars sought to achieve is far from being an exercise in lexicography as we understand the art today, it is, rather, a mode of philosophical and theological conceptual analysis. For, ultimately, the traditional scholar was providing a philosophical account of the essence of the concept and then matching this account with the putative nature of its referent. Semantic etymology is, therefore, an ontological-cumepistemological investigation of the object through an exploration of its name; it is not an investigation into the history of the word.

Arthur Jeffery's work The Foreign Vocabulary of the Qur'ān (1938) may be the paradigmatic example of a modern philologist 'correcting' the 'errors' of Muslim scholars on the origins of Qurānic terms. To be sure, Jeffery's contribution to our knowledge of the historical etymologies of these terms is undeniably extremely important, some transgressions in some of his claims notwithstanding. Yet the fact of the matter is that Jeffery's dismissive attitude towards traditional etymologies has led to regrettable misunderstandings, and became symptomatic of several later works in Qurānic and Islamic studies that misconstrued the purpose of traditional etymological accounts as well as their epistemological underpinnings. Traditional Muslim scholarship was operating under a fully different 'understanding of language' from that of Jeffery and his contemporaries, and within a different 'paradigm of meaning'. For brevity's sake, I will risk summarizing this difference into a single proposition that I will briefly explicate: modern philosophers of language are predominantly anti-essentialist in their approach to meaning. The same cannot be said of the pre-modern times. Although essentialism was not the only available model of meaning in late antiquity, it was without doubt the principal paradigm with which other theories had to contend. The Qurān was revealed in this 'essentialist' context. This last fact must be taken well into consideration in any analysis of the meaning of its terms, for otherwise we risk misconstruing its entire semantic hermeneutics, forgo its epistemological and ontological foundations and misread its message. Historical etymology, useful as it may be for our understanding of the pre-history of Qur'ānic terms, will certainly mislead scholars from achieving their aim of coming to grips with the message of the Qurān, and must therefore always be practiced in conjunction with its semantic counterpart, a point I will illustrate using the example of $z a k a \bar{t}$ in the last part of this article. 
Why reliance on Historical etymology will mislead the scholar from her purpose of understanding the message of the Qur'ann? The reason is quite complex, and the present article will merely touch the surface of this issue: the aforementioned essentialist paradigm of meaning that was founded on Aristotelian philosophy and reached a zenith in late antiquity, ${ }^{2}$ especially around the time of the revelation of the Qurān, must here be considered along with the fact that the Qurann is mutatis mutandis believed to be a manifestation of the Divine Logos. Logos-theology (and philosophy) is thoroughly intertwined with the essentialist school of meaning. This combination of the Logos paradigm and essentialist view of meaning, makes semantic etymologies, or the quest for 'essences', akin to the quest for the meaning ordained by God, short of saying, intended by God the 'Creator (read: Author) of the Cosmos'. Scholars that argue from the perspective of modern historical philology, therefore, not only misunderstand the practice of traditional scholars, they dismantle the most fundamental theological underpinnings of the 'Word of God' as Muslims understood it, namely, its realist conception of meaning and its ontological embeddedness

2 The idea of an essence in philosophy may be resumed by the claim that 'an entity has a quality or a set of qualities that are necessary for establishing its identity'; it was formalized in Plato's theory of forms, and through Aristotle's understanding of substance. Varieties of this idea remained current in scholastic philosophy, but came under severe criticism first indirectly in the work of John Stuart Mill and Charles Darwin and then directly by Philosophers, culminating most notably with Ludwig Wittgenstein. His notion that 'meaning is use' is an objection to the kind of essentialist thinking inherited from the scholastic tradition, see his Philosophical Investigation (1953, §138); see also Garth L. Hallett, Essentialism: A Wittgensteinian Critique (1991). Prominent arguments against essentialism also include Karl Popper's Objective Knowledge (1972); and Willard V. O. Quine, "Reference and Modality" (1953, 139-59) as well as Word and Object (1960). The modern philosophical scene, however, is not without proponents of essentialism notably: Hillary Putnam, "The Meaning of 'Meaning"" (1975, 215-71), and Saul Kripke, "Naming and Necessity" (1972, 253-355). Prominent authors on Darwin and essentialism in biology are David L. Hull, "The Effect of Essentialism on Taxonomy" (1965a, 314-26; 1965b, 1-18); and Ernst Mayr, "Typological versus population thinking” (1994 [1959], 157-16o) and The Growth of Biological Thought (1982). In modern linguistics, radical essentialism came under criticism from the father of modern linguistics, Ferdinand de Saussure, especially in light of his influential views on synchronie and diachronie and language as a system of arbitrary signs, the best introduction to the two models of language remains Saussure's own work, see Chapter 3, "La linguistique statique et la linguistique evolutive" (De Saussure 1995). Interestingly, the above critiques notwithstanding, contemporary empirical research in psychology has demonstrated the natural presence of default essentialist modes of thinking among children in early developmental phases. See the work of Susan A. Gelman in general, but especially: The Essential Child (2003). 
in reality. Assuming a diachronic or evolutionary model of language (and paradigm of meaning) for interpreting the text 'floats' the text's epistemological basis by suspending its ontological assumptions. Qur'ānic terms, as a result, would no longer refer to objects (concrete or abstract) that are based in the reality of the world as revealed by its author-cum-creator. These terms, short of reflecting eternal truths about the nature of the world, are handled as culturally constructed notions whose meanings are-always - in flux. As a result, the Qur'ān ceases to be the archetype of communication between Man and God through the faculty of 'meaning' which the Almighty bestowed on His subject; it collapses, instead, into a heap of Arabic terms that in a previous life were Hebrew, Aramaic or Syriac, and that might or might not reflect the ontology of the world. The essentialist understanding of language undoubtedly assumes a certain prima facie faith about the text and the authority behind it, which might not be shared by all. However, this faith must be-heuristicallyassumed for a proper theological investigation of scripture. Scriptural philology, one must concede, even when practiced in isolation from religious faith, remains implicated in theology.

The beliefs of the reader aside, the Qurān's self-understanding as the paramount communication between man and God is the main source of its authority. The very idea of a revealed scripture, especially in late antiquity, requires an admission to the existence of essences as mediators, on a variety of planes: they mediate the communication between God and Man, between meanings and utterances, and between words and things. The fundamental source of discursive authority to which the Arabic scripture appeals, is precisely this direct epistemic access to Divine Truth that language in general and the discernment of meanings in particular lends to the human subject. ${ }^{3}$ As far as the ethical dimension of this matter goes, the relation between 'knowledge of universals' that humans gain from a proper understanding of language and their ethical choices is not different from the classical philosophical debate over the relation between epistêmê (knowledge) and technê (art) and aretê (excellence, virtue). This debate regards the requirements and means to achieving virtue in the Greek tradition from Xenophon's discussions of the subject of the 'weakness of the will' to Aristotle's 'definition of the Good' in the Nicomachean Ethics. This includes Plato's famous discourses on the same issue in his various dialogues

3 As an example of the relevance of 'meaning' (over 'utterance') in this narrative, Jeannie Miller highlights the issue of God's freedom in the determination of meaning in his communication to Adam and its use in a gth century theological dispute regarding the person and attributes of Christ in the discussion between al-Jāhịiz, al-Nazzāām and a third mutakallim (theologian) in the famous epistle entitled Refutation of the Christians (al-Radd 'alä al-Nașārā), see her article "What It Means to Be a Son" (2016, 6o-79). Note that her reference to the 'theodicy' (mașlaha [sic.]) is unlike what is intended in the present article. 
that culminates in the Republic (Cooper 1975; Annas 1999; Walsch 1971) and that were passed on in the works of Muslim philosophers on identical question relating to 'knowledge of universals' (ma'rifat al-kulliyyāt, or al-māhiyyāt) and ethical conduct especially in Avicenna's extensive deliberations on knowledge and morality (McGinnis 2010, $209 \mathrm{ff}$.).

The dependence of ethical conduct on knowledge of essences and universals in Islam finds its roots in the Qurān, namely in sūrat al-Baqara and the context of verse 31. The verse, not incidentally, is the locus classicus for all subsequent discussions in the Islamic tradition regarding the-human-cum-divineorigin of meaning, and appears in the context of God's decision to establish a khalif $a$ on earth, the theodicy notwithstanding (v. 30). The direct access to meaning that language affords to humans, the epistemological realism that this understanding of language presupposes, is established, in Muslim scripture, as the fundamental premise for human salvation. It is precisely because God and Man share a fundamental linguistic resonance' (if one may use the acoustic metaphor) that - knowledge of - the truth is possible and with it, moral truths, and consequently redemption from evil. God-man communication is the epistemological basis for man's moral 'covenant' with God and the justification of his ethical knowledge. The human ability to acquire knowledge as well as its innate susceptibility to meaning is the Spirit $(r \bar{h} h)^{4}$ that God breathed into Adam (cf. 15:29; 38:72; 32:19); it is equally the Revelation (also rūh) that was made to the Prophet Mohammed to communicate the Quràn to his community (cf. inter alia $26: 193 ; 42: 52 ; 17: 85$ ); and it is the Spirit that was sent to Maryam so that she bears the Man-Logos, her son 'Īsá al-Masị to redeem humanity (cf. rūh in 66:12; 21:91; 19:17 and 3:45 for kalima). The basic meta-ethical assumption in this line of discourse is that overcoming - the problem of-evil is premised on 'knowledge'; an idea that has accompanied humanity—at least—since Socrates, and that was canonized in the Muslim scripture's account of the creation of man. ${ }^{5}$ The here proposed interpretation of 'allama Ādam al-asma ' as a reference to universals and universal meanings is reflected in the commentary of al-Rāghib al-Iṣfahānī (d. first half of fifth/ eleventh century) on the verse in question, who construes the verse as a reference to knowledge of universals, essences and other abstract entities. The

4 For a summary of references to the term in the Qur'ān and commentaries see Sara Tlili's "From Breath to Soul" (2017, 1-21).

5 For the pre-history of the creation narrative and the 'learning of the names' in the Christian and Jewish traditions, see Reynolds, The Qur'ān and its Biblical Subtext (2010, $39 \mathrm{ff}$ ). 
nature and content of what God taught Adam, the modality of the event and their implications on matters relating to the origins of meaning and of Adam's divine endowments and religious duties is a matter of profound debate in the Islamic tradition. ${ }^{6}$ Of interest to us here is the nature of Adam's instructions and the implications of al-Iṣfahānī's interpretation of the verse on our understanding of Islamic meta-ethics, moral epistemology and the role of etymology in defining moral concepts. Etymology was the scholar's tool for retrieving that primordial universal communication, symbolized by the divine imparting knowledge of meaning upon Adam, and that has become obscured by the corruption of human usage of words and the vicissitudes of history.

Little wonder, that sematic etymology was, to the Muslim tradition, a tool of theological investigation. Like its Greco-Latin Biblical and pagan counterparts, etymologia stood apart as an independent 'mode of reasoning,' Denkform (Curtius 1948) and was the overarching analytical method to start any exegetical or theological analysis, including for pagan religions (Dawson 1991). The observations of Mark Amsler regarding etymologia in the Greek and Latin tradition merits very close attention from scholars working on the Islamic tradition in the late antique and classical periods, for the relevance of his research program for the 'Islamic etymological tradition' is difficult to exaggerate, and impossible to miss. He writes: "Following God and Adam, the Christian interpreter searched for the origins of words to comprehend the origin of creation and, like the Stoics, to recover the cradle of reality and language. Calling things by their proper names at once articulated a full knowledge and repeated divine creation" (Amsler 1989, 84). The same is true of Islamic knowledge. Thus, God in all Abrahamic scriptural traditions, in a sense, speaks in etyma (El Masri $2 \mathrm{O} 2 \mathrm{O}, 26 \mathrm{ff}$.); in the way that $\mathrm{He}$ creates through divine speech.

6 For a useful survey of the different positions see Mahmūd Faraj al-Damirdāsh, Wa-'Allama $\bar{A} d a m$ al-Asmā' Kullahā (1996). For an analytical exposition see Kees Versteegh, "Linguistic Attitudes and the Origin of Speech in the Arab World" (1996, 15-31); also his "The Arabic Tradition" (1997, 227-284), and Landmarks in Linguistic Thought (2013); Henri Loucel, "L'Origine du langage d'après les grammairiens Arabes" (1963a, 188-208; 1963b, 253-281; 1964a, 57-72; 1964b, 151-187); Bernard Weiss, "Medieval Muslim Discussions of the Origin of Language" (1974, 33-41); and Mustafa Shah, "The Philological Endeavours of the Early Arabic Linguists" (1999, 27-46; 2000, 43-66), more recently a summary of the various positions in Mustafa Shah, "Classical Islamic Discourse on the Origins of Language: Cultural Memory and the Defense of Orthodoxy" (2011, 314-343). Most recently, Pierre Larcher, "« Et Allah apprit à Adam tous les noms ...»” (2020, 3-27). For an excellent comparison between the position of the theologians and the mystics (i.e. al-Qushayrī, d. 465/1073) on the issue of the origin of language, and meaning see Giovanni Carrera and Francesco Chiabotti, "Origine et Finalité du Langage dans le Moyen Age Islamique" (2011, 81-126). 
According to the Christian version of the Biblical narrative about naming, Adam named the animals before the Fall and before the pristine primordial language "collapsed with the Tower of Babel into homonymy, synonymy, equivocity, and lying" (Amsler 1989, 84; Borst 1957-1963). Now, far removed from this pristine moment, suffering the corruptive force of history and the inevitability of human error; lexicographers, grammarians, jurists, theologians and exegetes "operate in an imperfect and equivocal world" (Amsler 1989, 84). They therefore require etymological strategies in order to return to the original Word and the true meaning. In order to fully appreciate the significance of these claims for contemporary analysis of the text of the Qurān, it is important that we keep in mind the centrality of Word-Logos philosophy (and theology) in the structure of the Qur'anic worldview of Man's relationship to God and the world. Not only does the Word dominate over the human soul and the material world, by virtue of both being the reflection and the creation of the Word of God, but the Word-Logos theology is also the principle upon which languagerelated concepts in the Qurān are theologically and epistemically founded, (e.g. bayān, āya, kitāb, hikma, asmä', amr, mathal, qalam, qawl, hudā, ta'wīl, 'ilm, al-lawh, asāțīr, etc.; Dhaoudi 2001, 43-57.) The Qurān, viewed form this angle is a meta-linguistic communication, better: the meta-linguistic communication par excellence that appeals to humans' eternal receptivity to meaning and their ability to know in order to guide them through the temporal world. Man's ability to identify meaning in the world is his fundamental distinction over God's creatures, the rü $h$ that man shares with/from God will serve him to identify his purpose (telos, eschatos) and recognize reality and its truth. Little wonder then, that al-Rāghib al-Iṣfahānī understands the fundamental import of Q 2:31 in terms of Adam being made cognizant of essences and being sensitized to universal meanings. In his comments on the verse, al-Ișfahānī relays the early conviction regarding the naturalist-revelationist ${ }^{7}$ nature of language as well as his own conviction that essences and quiddities were the objects of the knowledge that God had imparted to Adam:

... the correct [claim] is that knowledge of reality [that God transmitted to Adam] relates to [Adam's] cognizance of the 'origins' (alt. 'principles', lit. 'roots', also pos. 'etyma', Ar. al-ușūl) that encompass the 'corollaries' (alt. 'derivatives', lit. 'branches', Ar. al-furū'); as well as universal meanings that encompass particulars, such as knowledge of the essence of 'man' and 'horse'; as well as the laws that serve to identify the quiddity of a

\footnotetext{
7 “Wa-l-ṣaḥịhu mā dhahaba ilayhi l-jumhūru annahu tawqīf" (Ghrāb 1999, 143).
} 
thing, such as the principles of multiplication in calculation; as well as the states of dimensions and sums in geometry; as well as the 'principles' that underlie several issues in jurisprudence, theology and grammar. ${ }^{8}$

If God bestowed upon Adam his cognizance of essences, quiddities and his overall attunement to meaning as claimed, and I concur, then the $a s m \vec{a}$ in Q 2:31 refers not so much to names, as much as to haecceities: 'the salient quality that uniquely identifies an object', which not incidentally matches the most common etymology proposed by the Islamic tradition for 'ism,' namely simá: 'alāma, the 'distinctive mark' of the object. ${ }^{9}$ Also, speaking of essences, quiddities and realities, it is fitting here to recall the etymology of 'etymology' and the meaning of the Greek etymon, i.e. from हैं ${ }^{\prime} \mu \circ \varsigma$ (étumos, 'true,' 'real') that is equivalent, in every sense, to the Arabic haqiqa, and bare that in mind for our understanding of al-Ișfahānī's reference to al-'ilm bi-l-haqìqa in the original Arabic text. The pursuit of semantic etymology is therefore, none other than the quest for uncovering the ultimate reality of the object, through the medium of language, which by divine decree reflects the ontology of the world. Language, then, properly analyzed and correctly understood, according to al-Ișfahānī, is not merely a vehicle of communication. Language is an epistemic source and the mirror of reality. With the aid of semantic etymology, the theologian is able to depart from the corruption of history and erroneous human use ${ }^{10}$ to return to that reliable epistemic source of knowledge of the fundamental nature of things. ${ }^{11}$

8 "wa-l-șaḥị̣u anna l-ilma bi-l-haqiqqati yata'allaqu bi-ma'rifati l-uṣuli l-mushtamilati 'alá l-furūi wa-l-ma'ānì al-kullīyati al-munțawiyatu 'alá l-ajzā̄i ka-márifati jawhara l-insāni wa-l-farasi wa-l-qawānīn allatī yu'rafu bihā hạaĩqatu l-shay'i mithla ușūli l-ḍarb fì l-ḥisāb wa-aḥwāl al-ab'ādi wa-l-maqādìri fì l-handasa wa-l-ūṣūl al-mabnìu 'alayhā l-masāil al-kathïra fì l-fiqhi wa-l-kalämi wa-l-nạ̣w" (Ghrāb 1999, 144).

9 See the grammarian's debate on the etymology of ism as reported by Kamāl al-Dīn al-Anbārī, in al-Inșā f fı Masāil al-Khilāf (1997). Ism, the Bașrans argued meant 'sign' 'aläma, while the Küfans argued for 'elevation' sumuww read: 'saliency' thus 'haecceity' (al-Anbārī 1997, n. 1, vol. 1, 6-15).

10 'Coinage' and the act of 'coining'; 'striking a piece of metal to turn it into monetary unit' is a known metaphor for devising a new name. The analogy with coining a term may be extended a little bit further: like coins loose the imprints on their surfaces with repeated use, words, too loose their original 'coinage' or intended meaning as generations of speakers change. The process of finding the original print of the 'coining' is akin to the etymologist's work, $\mathrm{s} /$ he will need to see several comparable coins to determine the original form, like the etymologist considers the different uses of the same lexeme to determine the meaning of a particular use or an obscure derivative word.

11 Compare this to the notion of the Edenic purity of names in Christianity, and the role of etymology in excavating the originally communicated meaning. See Amsler, Etymology 
al-Iṣfahānīs interpretation of Q 2:31, makes the tawqîf-iștilāḥ debate otiose as far as the epistemological validity of etymological investigations goes. ${ }^{12}$ As long as we concede that 'meaning' is transcendental in the sense that it is not a mere product of human thought and representation, it makes no difference if meaning was wedded to words by God or by Man, or, if you wish, by nature or by culture. Words may mean things by themselves, or through imposition by God, or through human imposition or by a combination thereof, whatever it may be, the nature and character of 'meaning' remain untouched. Little wonder, then, as Versteegh remarks, that "[al-ușūliyyūn] were not interested in the process of invention, but in the result: language, whoever initiated it, has been established once, and is characterized by its givenness" (Versteegh 1996, 15-31, 26). The origin of this 'givenness' of meaning is the crux of the matter in Q 2:31, not the origin of speech. The debate on the 'origin of language' may have gained importance and notoriety because it mimics the debate regarding the creation of the Qurân, yet the overarching theological lesson to be derived from $Q$ 2:31 still pertains to the more significant issue of the origin of meaning and the possibility of acquiring justified and reliable knowledge or 'mental content'13 that has practical worth for choosing proper moral conduct. Etymology, for its part, is a path designed to restore our access to that 'given content'.

and Grammatical Discourse (1989, $149 \mathrm{ff})$, also his article "Literary Onomastics and the Descent of Nations: The Example of Isidore and Vico" (1979, 106-116).

12 It may be useful to recall on the margin here Versteegh's comparison of tawqüf and ișțilăh with the Greek physis and thesis and relate this to Plato's Cratylus where the two positions are defined, and a middle-position is carved out and defended. Cratylus claims that "the simple truth is that anyone who knows a thing's name also knows the thing" (Plato 1997, 151, no. 435D). Hermogenes position was the opposite which he defended unyieldingly: "no one is able to persuade me that the correctness of names is determined by anything besides convention and agreement" (Plato 1997, 103, no. 384C). Socrates adopts the middle-position, by demonstrating that etymology was an undeniably useful tool of investigation of the essential qualities of things (Plato 1997, $128 \mathrm{ff}$, no. 410). The argument is identified by Amsler, Etymology and Grammatical Discourse (1989, 32-33), Plato: Complete Works (1997). For a short essay on the issue of epistemology and etymology in Plato's dialogues see Julia Annas, "Knowledge and Language: the Theaetetus and the Cratylus" (1982, 95-114).

13 To be sure, the debate about the creation of the Qurān may be read as an expression of the more general and more abstract question about the origin of meaning as such. It remains a fact, however, that they are two different matters that are settled with different arguments. 
We may therefore speak of the — phenomenological — 'givenness of meaning,'14 which I have referred to borrowing the Logos concept from the Greek philosophical and Christian theological traditions, notwithstanding the complex particularities of the Islamic understanding of the notion. One important implication of this realist conception of the origin of knowledge and meaning is that man [the subject] is epistemologically rooted in the world [the object] through language, thus barring any significant form of idealism, epistemological skepticism or a subject-object separation. This in turn implies that man's grasp of the world is 'real' and that human concepts are 'founded' in and arise from the ontology of the world. These concepts, however, are inevitably adulterated by human culture, like the prophetic messages that inevitably suffer the fate of corruption and oblivion in the course of human history. Both 'meaning' and 'revelation' are instances of an 'ideal' having been forgotten, fallen into ruin and were buried by the debris of the 'historical'. The task of etymology is thus to unearth the original usage that history has covered under layers of faulty human usage. This etymological 'truth' is reached through something that is not dissimilar to that pursued for producing a legal ruling (hukm shar 'ī): $\ddot{j m m} \bar{a}^{c}$ 'community consensus' on the original meaning of the lexeme is achieved by appeal, first, to the correct usage of language in the community (the canon, pre-Islamic poetry and the pure Arabic tongue), and second, by appeal to analogical inference, i.e. qiyās. The resulting etymon, așl al-ma'ná, is an account of the 'true' or 'real' nature of the object thus named, i.e. its haqiqa. For our study of ethical concepts, the epistemological relevance of the 'rootedness' of language in the ontology of the world implies that ethical concepts are real entities that reflect human nature and its relatedness to the world. Adherence to the moral-cum-epistemological implications of this 'conceptual rootedness' is equivalent to living according to 'God's command' (Ar. amr Allāh, cf. Heb. 'āmar: 'word') and in line with 'human nature' (Ar. fitra). The perfect and archetypical example thereof for the Muslim believer is the revealed Qur'ān and the Prophetic sunna. This understanding of the role of language in mediating our epistemological relation to the world has significant implications on the way we conceive moral concepts, and arguably

14 On the universality of meaning, we may consider the relevance of the famous claim by the ubiquitous literary critic al-Jāhiz (d. 255/868), who claims that máná is universal and identical for the speakers of the different languages, "The meanings lie in the street, and non-Arabs and Arabs, Bedouin and city-dwellers alike know them; the real problem is setting up the right metre and choosing the words" wa-l-ma ānī mațrūhatun fì l-țarīq ya'rifuhā l-a'jamīwa-l-Arabīwa-l-badawì wa-l-qarawì wa-innamā l-sha'n fì iqāmat al-wazn wa-takhayyur al-lafạ (al-Jāḥiz 1965, 3:131-132; translation from Versteegh 1997, 251). 
supports a form of moral intuitionism not unlike what has been suggested by G. E. Moore and others (Craig 1998).

Returning to the particularity of the moral issue and the context of Q 2:31, the theodicy; the verse's representation of man's acquisition of language comes as a direct response to the problem of evil that has accompanied Adam and his progeny almost since the beginning of creation. The asm $\vec{a}^{3}$-verse occurs in the context of God informing the Angels of His plan to establish a successor on earth (inni jāil fì l-ardi khalîfa). In Islamic theology, the khiläfa-verse and Man's privileged position on earth are the foundational justifications for human theo-political governance, and the verses must therefore be read as a general abstract account of human nature vis-à-vis its existential condition on the individual and political levels. After God's declaration of His intent, the response of the Angels to the divine decision regards the new creature's propensity to shed blood and sow the seeds of corruption (yufsidu fiha wa-yasfiku al-dima $\bar{a}^{\prime}{ }^{15}$ The angels' anticipation of moral evil from the khalifa is nothing other than the Qurānic articulation of the 'problem of evil' and the corruption that will always accompany Adam's descendants during their historical career on earth, illustrated by Adam's fall and his sons' quarrel that will lead to fratricide. Yet God's foreknowledge escaped the angels knowledge, and $\mathrm{He}$ demonstrated His mercy by teaching Adam all the names (wa-'allam Ādam al-asm $\bar{a}^{3}$ kullaha $)$, of which the Angels were, and remained, ignorant. Adam, will indeed err (2:36), not incidentally, deceived by that one Angel that misjudged the superiority of Adam's epistemic endowments. God will condemn the renegade Angel to an inevitable eschatological rectification but suspend Adam's judgement with a chance for repentance in the here-and-now, before making another 'verbal' or 'scriptural' communication with him (fa-talaqqá $\bar{A} d a m$ min rabbihi kalimāt, 2:37). The communication of the epistemic asma $\bar{a}$ and the later communication of the prophetic kalimät are the solution to the theodicy that was already - foreknown — in the Angels' protestations. Adam's ability to discern meaning that is 'given' by the order of things and is mirrored in language is/was the key to his salvation. Adam and his progeny have access

15 G. S. Reynolds takes the designation of Adam as a khaliffa to be comparable to the Biblical idea that man was created in the image of God. I am assuming that the acquisition of the Logos in the Q 2:30 is in many ways equivalent of the physical metaphor of the imago Dei and with similar theological implications. Reynolds writes: "The creation of Adam as the khalifa of God (Q 2:30) can mean nothing else, if what is understood by imago Dei is nothing physical. And indeed for the Church fathers this phrase cannot redound to Adam's looks", Reynolds focuses on the notion of the vicegerent, I think the emphasis is on the communication of the Logos, the distance between the two however, is a short one. See The Qur'ān and its Biblical Subtext (2010, 51). 
to meaning and truth, should they seek it, by divine decree, through language, despite the inevitability of human error and the cumulative corruption of history that prophecy periodically rectifies. Language and meaning (al-asmä) become a reference to that 'ideal' moment of meaning and man's ability to communicate, understand and realize knowledge about otherwise mute and inanimate objects.

This 'meaning' (ma'ná) ${ }^{16}$ includes the semantic worth of words and 'sense' of speech, the inner symbolic and the true interpretation of words, deeds, events. It equally includes the 'meanings' of objects, in the sense of them being 'indications' of other things (like smoke to fire), their 'value', and finally their 'purpose' (Phil. telos, Theol. eschatos) in the order of creation. Adam is a 'semantic creature', as it were, in the broadest sense possible, i.e. of being able to realize the significance, worth and implication of words, events and objects in his word. This multiplicity of senses in the concept of ma'ná is elegantly captured in the function of the act of $t a^{\prime} w \bar{l} l$ in the Qurann, especially in the context of the narrative of Joseph as well as Moses and his wise companion. ${ }^{17} \mathrm{The} t \mathrm{ta}^{\prime} w \bar{l} l$ (and with it ma'ná) of the visions of Joseph and the king in sūrat Yūsuf and of the acts of the companion of Moses in sūrat al-Kahf encompasses their immediate significance, their axiological worth and their teleological realization. ${ }^{18}$ Through this faculty to discern meaning, Adam was destined, from the beginning to obtain virtue and righteous piety and overcome the problem of evil. The divine 'givenness of meaning' is thus inseparable from his moral salvation. Discussion of the connection between knowledge of universals and discernment of meaning in terms of principles and universals ${ }^{19}$ on the one hand and

16 For a rich philosophical discussion of the meaning and use of the concept of máná in the Islamic tradition, with special focus on its equivalence on the modern concept of 'mental content' see Alexander Key, Language between God and the Poets (2018).

17 Cf. the Q 12:6, 21, 44, 100, 101; Q 18:87, 82.

18 See "Yūsuf: Ta’wīl-Interpretation and Eschatological Realization" (el Masri 2020, 296-299).

19 When we speak of 'knowledge' in this context, two sorts of knowledge ought to be distinguished, a practical and a theoretical sort, or 'knowledge how' and 'knowledge that', both of which are necessary, albeit the latter is the more fundamental, and if properly pursued, will lead to the former. One sort relates to the practical deliberation on specific actions and the other to the abstract epistemic consideration or theoretical enquiry into the fundamental truths or principles regarding that action. A physician (to take a favorite example from the classical philosophical register) needs to make practical decisions on whether to prescribe one medicine or another for the ailment she is trying to heal. Her making the right decision on the sort of medicine is key to curing the ailment and will therefore affect how well she is considered as a physician. Yet her being a 'good physician', apart from resting on knowledge of such practical matters, primarily rests on her understanding of her art as a physician, namely, restoring people to health and making sure 
human virtue on the other is common to both the Islamic and the classical philosophical tradition and has regained prominence of late in modern moral theory (Murdoch 1970; Murdoch 2003). The universal knowledge that God 'taught' Adam is 'given', in the sense that it is foundational and innately recognized by an impartial intuition; and prophecy rectifies misconception, should the intuition become corrupted. These are the epistemological foundations upon which humans can determine the right moral conduct.

With this background, one can better understand how Muslim scholars construed the semantic etymologies of the Qur'ān's moral concepts, and integrated them into the Muslim's understanding of her personal and communal self. We may focus, as an illustrative example, on the case of one revealed moral precept that bears directly on the life-condition of the human subject: the Qurān's injunction to perform zakāt. Already, when we speak of the meaning of $z a k \bar{a} t$, we should recall that the our discourse is ambivalent in its reference to the meaning of the term zakāt and the meaning of the object zakāt. The ambivalence between the de re and the de dicto may be given expression in our investigation by separating three layers of meaning identified above: the semantics of the term ' $z a k \bar{a} t$ ' (its 'significance'), the axiological meaning of the act of tazkiya (its 'value') as well as the former's teleological/eschatological meaning (its 'purpose' and 'consequences') in the order of creation. The semantic, axiological and teleological 'meanings' of the object and its name, as we shall see, cohere with each other. In any case, Muslim scholars operated

they remain healthy. If the physician intentionally ignores, or is simply ignorant of the 'principle' task of her vocation, then whatever success she may have, which will be less likely, will not make of her a 'good' physician. For that, she needs both sorts of knowledge, practical and theoretical. However, and whereas the 'theoretical' knowledge will lead her to enquire about the 'practical' counterpart, the opposite is not true; for it is the desire to fulfill the 'principle' objectives of the art that guides her practical actions. If she has no such 'principle' aims, then her practical actions are in a way 'pointless', even when they lead to curing the ailment. It is therefore knowledge of the theoretical or universal principles that are primary for her success. In other words although this knowledge of principles is not sufficient, it is necessary, for they guide her actions, determine what kind of practical knowledge she will seek to acquire and ultimately, make her a 'good' physician. In the broader meta-ethical discussion, this form of reasoning about the purposes of an action, the requisite knowledge to achieve it and the 'excellence in the art' that this will lead to it, is applied, mutatis mutandis to the purpose of human conduct as such and to the general definition of virtue. For our purposes here, suffice to note that, proper theoretical deliberation on the very idea of an undertaking is indispensable knowledge for the attainment of virtue. 
under this assumption when they investigate the meaning, they uncovered the essence or așl of both word and object (or 'act' in the case of $z a k \bar{a} t$ ). As a general background to our conceptual analysis, we will start with observations on the root $z-k-w$ in the Semitic languages and the Biblical tradition, before observing its use in the Qurān. These observations will situate the semantic etymological claims of Muslim scholars within the broader perspective of the Biblical tradition as reflected in the historical etymology of the term.

The root $z-k-w$, archeologist and philologists ${ }^{20}$ tell us, has been used, since pre-historical times, in the senses of 'purity,' 'cleanliness,' 'refinement,' 'exemption from guilt,' 'freedom from claims' and similar uses that emphasize the notions of 'purity' from dirt and pollution as well as 'freedom' from guilt or fault. Moreover, we can see from the various entries that the quality of a person being 'pure' and 'free' of material or spiritual pollution is linguistically-and arguably ontologically—related to the notion of being 'favored' by the superior power that be. 'Purity' leads-logically and causally—-to 'favor', 'distinction' and 'election.' The power bestowing the 'favor' and the 'distinction' can be a King that commutes a sentence or frees a slave, as well as God that emancipates a soul or elects a people. ${ }^{21}$ These meanings can also be found in the Biblical tradition. Not only do we have attested uses in the Hebrew Bible in senses $^{22}$ relating to 'charity' and 'purity', not to mention phonetic association

$20 \quad$ For example, the Akkadian $z-k-w$ relates to 'clarity,' 'purity,' 'exemption from tax,' 'dehusked grain,' 'free, ' 'exempt,' 'freed for temple service' (see Black, George and Postgate 200o, 443); the Assyrian zakû, zakūtu, zakitu equally relate to notions of 'cleanliness,' 'refinement,' 'freedom from claims,' 'obtaining clearance,' 'freeing a slave' (Roth, Oppenheim and Reiner 1961, 23 ff.).

21 Suleiman Bashear offers a rich list of the Semitic cognates with their meanings, I was, however unable to verify all of his sources, see his article "On the Origins and Development of the Meaning of Zakat in Early Islam," (1993, 84-113); examples from Bashear include the Ugaritic Uzakki, 'freeing a town from works due to the king'; the Phoenician roots zK/A refer to things that are 'pure' and zKI to being 'not guilty', 'free of [criminal] charge'; Ge'ez ZKH refers to 'purity'; Tigre and Gurage zKW 'tax paid to the local chief and a present'; Amharic zKW, 'food either begged for by poor students or given by rich people to the poor and the priests'; Sabaean ZKW 'charity for the poor,' 'tax.'

22 The institution of $z a k \bar{a} t$ has known precedents in the Christian and Jewish traditions, with some scholars assuming a Syriac origin of the term (Bell 1953, 166), others refer to zakutha, which means 'purity' and 'merit' and believe that it is very likely that it was used by Jews and Christians of Arabia to denote 'alms' (Robinson 1999, $112 \mathrm{ff}$ ); the same applies to voluntary charity șadaqa, which early lexicographers derive from Arabic terms relating to 'truthful', it is likely a calque of the post-biblical Hebrew tsedaqa 'righteousness' and 'alms' as does the Syriac zedqetha (Robinson 1999, 114). The Aramaic thesis was also proposed by Joseph Schacht, who notes that "Muslim scholars explain the word from Arabic as meaning 'purity' or 'increase." But adds that "in reality it was borrowed in a much wider sense by Muhammad from Jewish usage (Hebrew-Aramaic zāküt)" (Schacht 1913-1936, 
with the root s- $d-q$, that yields notions relating to 'virtue', 'righteousness' and 'alms', but the Peshitta presents us also with more than a handful of uses that relate to the senses of 'victory', 'justification', that leads, after qualification, to the sense of 'redemption.' ${ }^{23}$ John Wesley Etheridge comments, in his translation of Romans $5: 18,{ }^{24}$ on the Syriac zokutho (tr. 'acquittal') by supplementing it with an exegetical comment relating the Syriac term to the Latin notions of victoria, innocentia, justificatio (cf. succor, clearance, justification) and the Hebrew zakah, in terms of purum fuit, purum pronunciavit (make or declare free [of fault or sin]). The Christian theological notions of 'justification from sin, ${ }^{25}$ 'exemption from suffering', and 'succor' against overwhelming odds retain the 'essential' ideal. Although the Christian understanding of the concept differs - theologically — from the Islamic, some 'essential' etymological affinities are retained. ${ }^{26}$ For we do observe, that the Latin concepts all relate, logically

1202-1205). Similar claims and observations were made concerning șadaqa, suggesting it is a transliteration of the Hebrew șêdăka which originally meant "virtue" or "honesty." We are also told that ședank $a$ was used by the Pharisees to denote what they considered the principle duty of the virtuous Israelite: 'almsgiving' (Schacht 1974, 654-5), this observation is contradicted by Jeffery's material $(1938,153)$. Charles Torrey claims that $z a k \bar{a} t$ and șadaqa are loan words from the North Semitic languages, corresponding in particular to Aramaic zakūt and șidakta and Hebrew șidaka, respectively. The Aramaic zakūt he claimed originally meant "purity" and was used by both Jews and Christians in the sense of "virtuous conduct". To this he added the view that "the latter term (șidakta) was widely used in Aramaic speech to mean alms" (Torrey 1933, 141).

23 The root $z-k-w$ as well as $d-k-w$ relate, in various forms, to notions of 'purity'; e.g. Matthew 12:20; Luke 1:51, 11:22; John 5:4, 16:33; Romans 3:4, 5:18, 8:37, 12:21; Hebrews 11:33, ${ }_{2}$ Peter 2:19, 2:20; 1John 2:13-14, 4:4, 5:4-5; Revelation 2:7, 2:11, 2:17, 2:26, 3:5, 3:12, 3:21, 5:5, 6:2, 11:7, 12:11, 13:7, 15:2, 17:14, 21:7; 1Corinthians 9:24, 15:54, 15:55, 15:57; Philippians 3:14. For an example of $d / d h-k-w$, compare Q 5:3 to Hebrews 13:4 and James 3:17.

24 "As then on account of the transgression of one was the condemnation of all men, so, on account of the righteousness of one shall there be acquittal unto the life of all men" (Etheridge, Romans 5:18).

25 "A biblio-ecclesiastical term; which denotes the transforming of the sinner from the state of unrighteousness to the state of holiness and sonship of God" (Pohle 2010).

26 One ought to address Walid Saleh's contribution to the subject of etymology and the Qurān, a duty I have been postponing for a while (2009, 649-698). A proper response is planned and will hopefully see the light before long. Saleh's article, apart from suggesting an elegant argument about the possible pagan backgrounds of the character of the residents of paradise, offers a rare and very rich discussion of the important subject of etymology in Qur'anic Studies and provides the definitive response to the sort of arrogant and irresponsible musings of modern Qurān scholars, not least of which the last harum-scarum foray of the so-called Syro-Aramaic 'Lesart'. For the current purposes, I should mark one important point of disagreement with Saleh's critique that ensues from a deeper disagreement about the applicability of Barr's claims to the Quraann (1961). James Barr's reference to 'etymology' is explicitly to the 'historical study' of the origins of 
though not necessarily theologically, to the notion of 'election', or God's favor and grace to specific groups or individuals, which can be read into many of the Qur'ān's uses of the root $z-k-w .{ }^{27}$

words (Barr 1961, 107) and the fallacy he is referring consists in "giving excessive weight to the origin of a word as against its actual semantic value" (Barr 1961, 103). What I have been referring to as 'semantic etymology' appears in Barr's work as the 'root' and recurs throughout his work, under different rubrics (e.g. comparison with platonic ideal: Barr 1961, 100 ff.; onomastics: Barr 1961, 109, etc). Barr, the theologian, was not against the use of 'the root' for Biblical interpretation; in fact he recognizes it as a common instrument of theological analysis in his work through and through and has different nuanced responses to the various scholarly discussions on the subject. This kind of textual hermeneutics is not the target of his critique; its abuse, through the excessive incorporation of historical etymology into semantic analysis, however, is. In that sense, Barr is right to remind us that a Biblical word means what it means in the language it is used, and that etymological analysis can only provide supplementary information. My position is that Barr's statement, perhaps correct for the Bible, does not hold true for the case of the Qurān, thus my disagreement with Saleh's work that applies Barr's critique to the Arabic text, without qualification. As the example of $z a k a \bar{t}$ here suggests, and as shown in my monograph on al-Ākhira, the Qur'ān's theological rhetoric is thoroughly engaged in interand intra-linguistic etymological punning (i.e. historical and semantic etymologizing). The process of Arabization of Biblical knowledge that is reflected in the Qurān is mainly carried out through contextualizing Biblical (Syriac, Aramaic and Hebrew) terms within the poetics of Arabic semantics. The 'root', which we must recall was a Muslim discovery in light of the Qur'ān, was introduced for the analysis of Qur'anic terms first and foremost, becoming the instrument of choice for all varieties of Qurān-related scholarship ( fiqh, kalām, tafsìr, etc.). As such, one must agree with Barr and Saleh that the "excessive reliance" on historical etymology is dangerous for reading any text. In the case of Quranic terms, however, especially the theological-cum-technical variety, their Syriac, Aramaic and Hebrew backgrounds is not only relevant, but, I argue, necessary for understanding the shift incurred by the Arabic layer. Hence my suggestion that a hybrid form of etymology (Arabic semantic and Biblical historical) is the best — and perhaps only —adequate instrument for revealing the epistemic transfer taking shape in the Qurān while demonstrating the specificities of the Islamic theological meanings, see chapter 2.1 "Etymology, Semantic and Historic: Arabic-Scripture" (el Masri 2020).

27 The root $z-k$-w occurs 59 times in the Qurān, in seven forms. In 24:21 mā zakā minkum min ahadin abadan, Badawi and Abdel Haleem understand this in terms of "to reach a level of acceptability (by God), to attain enough purity, to increase in purity". This complementarity in the different strands of meaning of the notion is also reflected in other verbal uses where the act of God is contrasted with the act of Man, a clear example of this is 4:49; God addressed the people of revealed scripture in general and the Jews in particular, He berates those that 'yuzakkūna anfusahum, i.e. 'elect themselves' or 'feign purity,' and answers that it is He that 'elects' and/or 'purifies' yuzakki whomever He wants (cf. also 53:32 fa-lā tuzakkū anfusakum, and 2:129, 2:151, 2:174, 3:77, 3:164). In 9:103 the injunction to the prophet that he takes some of the believer's property to purify them, the use of tuzakkihim may also be interpreted in terms of purifying them as well as promoting their chances of election (khudh min amwälihim șadaqatan tuțahiruhum wa-tuzakkīhim bihā). In short, in almost all cases where the verbal form is used, the senses of 'purification,' 
The notion of tazkiya in some of the verses of the Qur'ān (cf. e.g. 24:21, 4:49) is comparable to that of 'election' [for salvation] in Christian theology, although, unlike, say Calvinist, election, Islamic salvation insofar as it is articulated with the root $\mathrm{z}-\mathrm{k}-\mathrm{w}^{28}$ is very much conditional upon pursuing acts that justify the divine tazkiya. These acts, not incidentally, consist, essentially, of performing the various strands of zakāt (paying alms, purifying one's deeds, etc.). The polysemy of the term zakät, therefore, between the sense of 'physical, moral and financial acts of purification' and the sense of 'redemptive election' reflect the fact that the act of $z a k \bar{a} t$ (purification) on the part of the subject leads to, and may even be equivalent to a tazkiya (election, growth, blessing) by God. That 'virtue is its own reward' fittingly applies here if we consider the etymological connection that reflects the complementarity between the two strands of meanings. The polysemy of the Arabic term, therefore, reflects the theologi$\mathrm{cal}$ and causal relations between the subject's act of 'purification'29 (tuhr), and the divine recompense of 'growth' (namä), and 'blessing' (baraka), which I

'prosperity' and 'election' are integrated through equivocal uses. Consider the causative zakkā (cf. 91:9 qadd aflaḥa man zakkāhā and 24:21, 62:2) and the reflexive tazakkā (20:76, 35:18, 35:18, 79:18, 80:3, 80:7, 87:14, 92:18), one may insert any of the three proposed meanings, and all three will produce reasonable, and complementary senses of the verses. Uses of the adj. elative, $a z k \bar{a}$ relates to 'choicer' or 'purer' acts, in 2:232 it relates to the management of divorce, in 18:19 to finding sustenance, in 24:28, 30 to decency and chastity being 'preferable' and 'purer'. As far as the use of the nominal, al-zakāt, 'almsgiving', the notions of 'purity', 'growth' and 'election' are not far below the surface meaning, and this is especially visible in 23:4 wa-l-ladhina hum li-l-zakäti fä́ilūn. The verb fa'ala in the verse indicates that the Zakāt is here not—only—alms being 'paid' (cf. ìtāa al-zakāt), but is the performance of complex acts that engender 'purity', 'growth' and 'election' thus the fäilün (cf. 2:43, 2:83, 2:110, 2:177, 2:277, 4:77, 4:162, 5:12, 5:55, 7:156, 9:5, 9:11, 9:18, 9:71, 18:81, 19:13, 19:31, 19:55, 21:73, 22:41, 22:78, 23:4, 24:37, 24:56, 27:3, 30:39, 31:4, 33:33, 41:7, 58:13, 73:20, 98:5). Finally, the two adjectival cases zakiyyan in 19:19 and zakiyyatan in 18:74 mean 'pure', first in the case of Mary's newborn, second of innocent soul that is 'pure of sin' in the case of the slain youth in the parable of Moses and the three mysterious acts of his wise company (Badawi and Abdel Haleem 2010, 399-400).

28 Comparable would be the broad notion of God's rahma, which like Calvinist election in this case, can be ordained by God, without it being preceded by an act that justifies it on the part to the subject, but bestowed as a simple act of grace by God.

29 Needless to say, perhaps, that the concept of 'purity' is fundamental to Christianity, and underlies a plethora of concepts of the faith, this is visible in the notions of 'innocence' from sin, the original 'purity of the soul', Asceticism and more. For the connection between purity and almsgiving, see the oft-cited and very useful work of Roman Garrison, Redemptive Almsgiving in Early Christianity (1993); the title of Garrison's work might be misleading, it is more than a work in the history of ideas, it presents a theological and historical investigation of the idea of redemption from post-baptismal sin, with an investigation of the possible conflict with the other notion that the death of Christ is the sole atonement for sin. For an overview of the theme of purity and almsgiving in 
interpreted here as 'election' or 'redemption'. The semantic etymology of the term zakāt that is commonly proposed in the Islamic tradition, we observe, encapsulates the semantic, axiological and teleological/eschatological meanings of - the act of - zakāt. Muslim scholars give an account of its essence, in terms of its intrinsic value and extrinsic results by stressing that the virtues of 'purity' and 'sacrifice' have broad personal-existential as well as social-political benefits, leading to the distinction and development of both individual and community.

The 'given meaning', consecrated in scripture, that purity and sacrifice have established personal and social benefits for both giver and recipient has been observed in various forms by historians of ideas ${ }^{30}$ and anthropologists. ${ }^{31}$ Similar notions underlie the very idea of distributive justice in moral philosophy, economy (i.e. investment) and of course philanthropy. The work of Abderrazak Belabes on $z a k a \bar{t}$ has given us one good roadmap towards understanding the multifaceted nature of the concept and its embeddedness in the various social sciences (Belabes 2019), demonstrating that the fit between the claims of semantic etymologists and the observations of the modern anthropologist deserves serious consideration. This may be a suitable response to the modern reader of religious literature in general and the secular in particular, who are generally loath to the very notion of transcendental essences underlying meaning in language. The secular reader is prone to dismiss the sort of essentialist accounts provided by the semantic etymologists as philosophical-

Rabbinic literature with a useful overview of the sources see Alyssa M. Gray, "Redemptive Almsgiving and the Rabbis of Late Antiquity" (2011, 144-184).

It may be reasonable to assume that the moral basis of the notion of 'purity' relate to the institution of sacrifice, which is retained in the monotheistic tradition, see the study of Andrej and Ivana Petrovic, Inner Purity and Pollution in Greek Religion (2016); for a modern discussion of the notion see the work of Virginia Sarah Smith, Clean: a history of personal hygiene and purity (2008).

31 The case for the social and psycho-moral benefits of sacrifice and gifts was famously made by the French anthropologist Marcel Mauss (1925), Essai sur le Don. Forme et raison de l'échange dans les sociétés archaïques, Marcel Mauss, Oeuvres/ 1 Les fonctions sociales du sacré (1968). For a wealth of general references to the relevant anthropological literature on the specific issue of $z a k a \bar{t}$ see Jonathan Benthall's work on 'charity' in the Islamic world: "Financial Worship: The Quranic Injunction to Almsgiving” (1999, 27-42); The Charitable Crescent: Politics of Aid in the Muslim World (with J. Bellion-Jourdan, 2003); "Islamic charities, faith-based organizations and the international aid system" (2008, 1-14); for a collection of his most important contributions, including some of the listed above see Benthall 2016. 
or theological-fictions that bestow a certain quality of timelessness and immutability to notions that are immersed in cultural temporality and local historicity, and that change and evolve like everything else. Yet the ongoing philosophical debates about essences and conceptual relativism is no ground to dismiss the anthropological worth of theological concepts. Indeed, anthropology, as an institution, may be read as the scientists' attempt to make sense of the persistence of religious institutions and concepts. The 'givenness of meaning' may be difficult to justify philosophically, it has however, undeniable anthropological worth.

I must stress the fact that the above discussion of semantic etymologies, essences and the givenness of meaning ought not to be understood as an argument in support of a hard realist position on the ontological status of religious concepts, for that would be too strong a claim, and is not the sort that can be reasonably maintained by the sort of arguments presented here. Moreover, the ontological status of religious concepts, according to the very scripture that christens them, is a matter of faith and is recognized trough knowledge-ofthe-heart; which is not the sort of knowledge that can justify philosophical certainty. The claim here made, rather, is far more modest: the work of semantic etymologists identifies scriptural concepts that, at least, accurately reflect anthropological realities. At the least, these realities become embedded in language and an investigation of common parlance and the longue-durée use of language can lend us valuable knowledge about our human and social natures. The historical etymology of zakāt, for example, reflects millennial cognitive habits and conceptions about, purity, prosperity and distinction. This 'embeddedness' may also explain the intuitive psychological and spiritual appeal of religious concepts in general, but especially concepts that are based on firm semantic etymological grounds of the sort that we find in the original languages of the Bible and the Qurān. The above observations are meant to offer a fresh approach to age-old ethico-religious concepts, and perhaps, a support-from language - of our moral intuitions. The intuitionist claim that fundamental moral claims are self-evident, that they can be directly apprehended, that they are foundational in the sense that they are accepted or rejected before rational justification is here supported by their embeddedness in the language that reflects man's anthropological reality. ${ }^{32}$

32 The ethical concept of fitra, commonly translated as 'nature' or 'natural intuition', according to the analysis here proposed, may be founded on the givenness of meaning, and man's ability to directly discern it, regardless of the language s/he speaks. 
All Muslim scholars, without exception, and regardless of school or theological commitment appealed to semantic etymologies in their exegetical, legal and theological claims about the canon. This is sufficient proof, it is safe to assume, that they genuinely believed that this form of analysis gives access to knowledge of the reality of things and therefore the ultimate meanings of words as God in the Qurān intended them. They always agreed on etymology as a strategy for the generation/discovery of meaning. The Arabic linguistic tradition and Islamic religious literature in general manifest a stable and systematic engagement with etymological analysis, in a way unprecedented in the Biblical tradition. Kitāb al-Ayn by al-Khalīl b. Aḥmad (d. 175/791) is arguably the first lexicon to cover an entire language and reflects the Islamic belief that the Arabic language is epistemically consistent and that it has an internal order that is phonetic-cum-etymological in nature (Haywood 1965). Like in the Chinese, Sanskrit, Greek and Latin traditions, the Muslims produced works on onomastics and glossaries of specific objects (Baalbaki 2014, $62 \mathrm{ff}$.), but the shift from there to a fully-fledged phonetic classification of the entire language coupled with the attempt to exploit the epistemological feature of language was unique to the Arab tradition, and the Qurān was instrumental in producing or at least accelerating that shift (el Masri 2020, $26 \mathrm{ff}$ ). After the event of the Qurān, etymological analysis was established as an epistemological tool of enquiry, which is far more significant than etymology's purpose as a lexical organizer. Scholars must, therefore, continue to consult and investigate semantic etymologies. In fact they are required to, if they want to establish the proper epistemic basis for Islamic theology today in new linguistic and cultural milieus (like the Biblical tradition established itself in the Arabian milieu). As past Muslim scholars debated the 'correct' or 'proper' semantic etymologies of central religious concepts, their theological commitments appeared through the sort of etymologies they suggested and advocated. ${ }^{33}$ These debates are far from finished. In fact with the new philological milestones now established in our knowledge of the historical etymology of Qurānic concepts, new and compelling arguments have been thrown into the arena, and these new contributions can only enrich our knowledge of Islam, its history, theology and conversation with the Biblical tradition.

33 A textbook example is the difference on the etymology of insān between the Bașrans and the Kūfans, see Kamāl al-Dīn al-Anbārī, al-Inșāff fi Masā̉il al-Khiläf(1997). The debate was mainly on the notions of ins 'familiarity' [through communication] and nsy 'forgetfulness' [Adam of his covenant with God cf. Q 20:115] (al-Anbārī 1997, n. 117, vol. 2, 8o9-812). 


\section{Bibliography}

Amsler, Mark. 1979. "Literary Onomastics and the Descent of Nations: The Example of Isidore and Vico." Names 27(2): 106-16.

Amsler, Mark. 1989. Etymology and Grammatical Discourse in Late Antiquity and the Early Middle Ages. Amsterdam: John Benjamins Publishing.

al-Anbārī, Kamāl al-Dīn. 1997. Al-Inșāfffì Masāil al-Khilāf, edited by Muhammad Muḥȳ̄ al-Dīn 'Abd al-Hamīd. Beirut: al-Maktaba al-'Așriyya.

Annas, Julia. 1982. "Knowledge and Language: the Theaetetus and the Cratylus." In Language and Logos, edited by M. Schofield \& M. C. Nussbaum, 95-114. Cambridge: Cambridge University Press.

Annas, Julia. 1999. Platonic Ethics, Old and New. Ithaca: Cornell University Press.

Aristotle. 2000. Nicomachean Ethics, edited and translated by Terence Irwin. Indianapolis/Cambridge: Hackett Publishing Company.

Baalbaki, Ramzi. 2014. The Arabic Lexicographical Tradition. Leiden: Brill.

Badawi, Elsaid M. and Abdel Haleem, Muhammad, Eds. 2010. Arabic-English Dictionary of Qur'anic Usage. Leiden: Brill.

Barr, James. 1961. The Semantics of Biblical Language. Oxford: Oxford University Press.

Bashear, Suleiman. 1993. "On the Origins and Development of the Meaning of Zakat in Early Islam." Arabica 40(1): 84-113.

Belabes, Abderrazak. 2019. "Zakat as a Pluridimensional Concept." International Journal of Zakat 4(1): 67-75.

Bell, Richard. 1953. Introduction to the Qur'ān. Edinburgh: Edinburgh University Press.

Benthall, Jonathan and J. Bellion-Jourdan. 2003. The Charitable Crescent: Politics of Aid in the Muslim World. London: I. B. Tauris.

Benthall, Jonathan. 1999. "Financial Worship: The Quranic Injunction to Almsgiving." The Journal of the Royal Anthropological Institute 5(1): 27-42.

Benthall, Jonathan. 2008. "Islamic Charities, Faith-Based Organizations and the International Aid System." In Islamic Charities, edited by J. Alterman and K. van Hippel, 1-14. Washington DC: Center for Strategic and International Studies.

Benthall, Jonathan. 2016. Islamic Charities and Islamic Humanism in Troubled Times. Manchester: Manchester University Press.

Black, Jeremy, Andrew George and Nicholas Postgate. 2000. A Concise Dictionary of Akkadian. Wiesbaden: Harrassowitz Verlag.

Bloch, Howard. 1983. Etymologies and Genealogies. Chicago: University of Chicago Press.

Borst, Arno. 1957-1963. Der Turmbau von Babel. Geschichte der Meinungen über Ursprung und Vielfalt der Sprachen und Völker, 4 vols. (in 6). Stuttgart: Hiersemann. 
Carrera, Giovanni and Francesco Chiabotti. 2011. "Origine et Finalité du Langage dans le Moyen Age Islamique." Kervan—Rivista Internazionale di studii afroasiatici 13/14: 81-126.

Chantraine, Pierre. 1970. "Étymologie historique et étymologie statique." Bulletin de la Classe des Lettres et des Sciences Morales et Politiques de la Académie Royale de Belgique 16: 8o-95.

Cooper, John M. 1975. Reason and Human Good in Aristotle. Cambridge: Harvard University Press.

Craig, Edward. 1998. Routledge Encyclopedia of Philosophy, 10 vols. London: Routledge.

Curtius, Ernst Robert 1948. Europäische Literatur und lateinisches Mittelalter. Bern: Francke.

al-Damirdāsh, Maḥmūd Faraj. 1996. Wa-'Allama Ādam al-Asmā̄ Kullahā. Cairo: al-Ma'had al-'̄̄lamī lil-Fikr al-Islāmī.

Dawson, David. 1991. Allegorical Readers and Cultural Revision in Ancient Alexandria. Berkeley: University of California Press.

De Saussure, Ferdinand. 1995. Cours de linguistique générale. Paris: Payot.

Dhaoudi, Mahmoud. 2001. "The Quranic View on the Cultural Divine Breath and the Human Distinctiveness." Islâm Araştirmalari Dergisi 5(1): 43-57.

el Masri, Ghassan. 2020. The Semantics of Qur'anic Language: al-Āhira. Leiden: Brill.

Garrison, Roman. 1993. Redemptive Almsgiving in Early Christianity. Sheffield: Jsot.

Gelman, Susan A. 2003. The Essential Child:Origins of Essentialism in Everyday Thought. Oxford: Oxford University Press.

Ghrāb, Muḥammad 'Abd al-'Azīz Basyūnī, Ed. 1999. Manhaj al-Rāghib al-Așfahānī fì al-Tafsìr ma' Tahquìq Muqaddimatihi wa-Tafsìrihi li-Sūratay al-Fätiha wa-l-Baqara. PhD Diss., University of Țanț.

Gray, Alyssa M. 2011. "Redemptive Almsgiving and the Rabbis of Late Antiquity." Jewish Studies Quarterly 18(2): 144-184.

Hallett, Garth L. 1991. Essentialism: A Wittgensteinian Critique. Albany: State University of New York Press.

Haywood, John A. 1965. Arabic Lexicography: its History, and its Place in the General History of Lexicography. Leiden: Brill.

Hubert, Henri and Marcel Mauss. 1929. "Essai sur la nature et la fonction du sacrifice." (1899). In Collection: Travaux de l'Année Sociologique, 1-13o. Paris: Librairie Félix Alcan.

Hull, David L. 1965a. "The Effect of Essentialism on Taxonomy: 2000 Years of Stasis. 1/2." The British Journal for the Philosophy of Science 15(6o): 314-26.

Hull, David L. 1965b. "The Effect of Essentialism on Taxonomy: 2000 Years of Stasis. 2/2." The British Journal for the Philosophy of Science 15(61): 1-18.

al-Jāḥiz. 1965. Kitāb al-Hayawān, edited by 'Abd al-Salām Hārūn, 8 vols. Cairo: Maṭba'at Muṣțafā al-Bābī al-Ḥalabī. 
Jeffery, Arthur. 1938. The Foreign Vocabulary of the Qur'ān. Baroda: Oriental Institute. Key, Alexander. 2018. Language between God and the Poets: Mana in the Eleventh Century. Oakland: University of California Press.

Kripke, Saul. 1972. "Naming and Necessity." In Semantics of Natural Languages, edited by Donald Davidson and Gilbert Harman, 253-355. Dordrecht: Springer.

Larcher, Pierre. 1995. "Où il est montré qu'en arabe classique la racine n'a pas de sens et qu'il n'y a pas de sens à dériver d'elle." Arabica 42(3): 291-314.

Larcher, Pierre. 2020. “« Et Allah apprit à Adam tous les noms ...» (Cor., 2, 31): L'Origine du langage dans la pensée islamique." In The Origin and Nature of Language and Logic: Perspectives in Medieval Islamic, Jewish, and Christian Thought, edited by Nadja Germann and Steven Harvey, 3-57. Turnhout: Brepols.

Loucel, Henri. 1963a. "L'Origine du langage d'après les grammairiens Arabes. 1/4." Arabica 10: 188-208.

Loucel, Henri. 1963b. "L'Origine du langage d'après les grammairiens Arabes. 2/4." Arabica 10: 253-281.

Loucel, Henri. 1964a. "L'Origine du langage d'après les grammairiens Arabes. 3/4." Arabica 11: 57-72.

Loucel, Henri. 1964b. "L'Origine du langage d'après les grammairiens Arabes. 4/4." Arabica 11: 151-187.

Mauss, Marcel. 1925. Essai sur le Don. Forme et raison de l'échange dans les sociétés archaïques. Paris: Presses Universitaires de France.

Mauss, Marcel. 1968. Oeuvres/1 Lesfonctions sociales du sacré. Paris: Éditions de Minuit.

Mayr, Ernst. 1982. The Growth of Biological Thought:Diversity, Evolution, and Inheritance. Cambridge, MA: Harvard University Press.

Mayr, Ernst. 1994 [1959]. “Typological versus Population Thinking." In Conceptual Issues in Evolutionary Biology, edited by Elliott Sober, 157-16o. Cambridge, MA: MIT Press.

McGinnis, Jon. 2010. Avicenna. Oxford: Oxford University Press.

Miller, Jeannie. 2016. "What it Means to Be a Son: Adam, Language, and Theodicy in a Ninth-Century Dispute." Journal of the Canadian Society for Syriac Studies 16(1): 6o-79.

Murdoch, Iris. 1970. The Sovereignty of the Good. London: Routledge and Kegan Paul.

Murdoch, Iris. 2003. Metaphysics as a Guide to Morals. London: Vintage Classics.

Petrovic, Andrej and Ivana Petrovic. 2016. Inner Purity and Pollution in Greek Religion: volume I: early Greek religion. Oxford: Oxford University Press.

Plato. 1997. Plato: Complete Works, edited by John M. Cooper. Indianapolis/Cambridge: Hackett Publishing Company.

Pohle, Joseph. 1910. “Justification.” The Catholic Encyclopedia, vol. 8. New York: Robert Appleton Company, available online: www.newadvent.org/cathen/o8573a.htm.

Popper, Karl. 1972. Objective Knowledge. Oxford: Oxford University Press. 
Putnam, Hillary. 1975. “The Meaning of 'Meaning.” In Mind, Language and Reality, 215271. Cambridge: Cambridge University Press.

Quine, Willard V. O. 1953. "Reference and Modality." In From a Logical Point of View, 139-159. Cambridge, MA: Harvard University Press.

Quine, Willard V. O. 196o. Word and Object. Cambridge, MA: MIT Press.

Reynolds, G. S. 2010. The Qur'ān and its Biblical Subtext. London: Routledge.

Robinson, Neal. 1999. Islam: A Concise Introduction. London: Routledge.

Roth, Martha T., A. Leo Oppenheim, and Erica Reiner. 1961. The Assyrian Dictionary of the Oriental Institute of the University of Chicago. Chicago: The Oriental Institute.

Saleh, Walid. 20o9. "The Etymological Fallacy and Qur'anic Studies: Muhammad, Paradise, and Late Antiquity." In The Qur'ān in Context, edited by Angelika Neuwirth et al., 649-698. Leiden: Brill.

Schacht, Joseph. 1913-1936. “Zakāt.” In Encyclopaedia of Islam, First Edition, vol. 4, 12O21205. Leiden: Brill.

Schacht, Joseph. 1974. “Zakāt.” In Shorter Encyclopaedia of Islam, edited by H. A. R. Gibb and J. Kramers, 654-655. Leiden: Brill.

Shah, Mustafa. 1999. "The Philological Endeavours of the Early Arabic Linguists: Theological Implications of the Tawqíf-Iștilāh Antithesis and the Majāz Controversy_-Part I." Journal of Qur'anic Studies 1(1): 27-46.

Shah, Mustafa. 2000. "The Philological Endeavours of the Early Arabic Linguists: Theological Implications of the Tawqīf-Isțilāh Antithesis and the Majāz Controversy-Part II." Journal of Qur'anic Studies 2(1): 43-66.

Shah, Mustafa. 2011. "Classical Islamic Discourse on the Origins of Language: Cultural Memory and the Defense of Orthodoxy." Numen 58: 314-343.

Smith, Virginia Sarah. 2008. Clean: a history of personal hygiene and purity. Oxford: Oxford University Press.

Tlili, Sara. 2017. "From Breath to Soul: The Quranic Word Rūh and its (Mis)interpretations." In Arabic Humanities, Islamic Thought: Essays in Honor of Everett K. Rowson, edited by Joseph Lowry, Shawkat Toorawa, 1-21. Leiden: Brill.

Torrey, Charles Cutler. 1933. The Jewish Foundation of Islam. New York: Jewish Institute Of Religion Press.

Versteegh, Kees. 1996. "Linguistic Attitudes and the Origins of Speech in the Arab World" in Understanding Arabic: Essays in Contemporary Arabic Linguistics in Honor of El-Said Badawi, edited by Alaa Elgibali, 15-31. Cairo: American University in Cairo Press.

Versteegh, Kees. 1997. "The Arabic Tradition." in The Emergence of Semantics in Four Linguistic Traditions: Hebrew, Sanskrit, Greek, Arabic, edited by Wout van Bekkum et al., 227-284. Amsterdam: John Benjamins.

Versteegh, Kees. 2013. Landmarks in Linguistic Thought Volume III: The Arabic Linguistic Tradition. London: Routledge. 
Walsch, James. 1971. “The Socratic Denial of Akrasia in Gregory Vlastos.” The Philosophy of Socrates: A Collection of Critical Essays, 235-263. New York: Anchor Books.

Weiss, Bernard. 1974. "Medieval Muslim Discussions of the Origin of Language." Zeitschrift der deutschen morgenlandischen Gesellschaft 124: 33-41.

Wittgenstein, Ludwig. 1953. Philosophical Investigation, edited by G. E. M. Anscombe and P. M. S. Hacker. Chichester: Wiley Blackwell.

Zaborski, Andrzej. 2004. "Etymology, Etymological Fallacy and the Pitfalls of Literal Translation of Some Arabic and Islamic Terms." in Words, Texts and Concepts Cruising the Mediterranean Sea, edited by R. Arnzen and J. Thielmann, 143-148. Leuven: Peeters. 